OPEN ACCESS

\section{Marine diatoms in polar and sub-polar environments and their application to Late Pleistocene paleoclimate reconstruction}

To cite this article: Xavier Crosta 2011 IOP Conf. Ser.: Earth Environ. Sci. 14012006

View the article online for updates and enhancements.
You may also like

\begin{tabular}{l} 
- A naturally occurring diatom frustule as a \\
\hline$\underline{\text { SERS substrate for the detection and }}$ \\
\hline quantification of chemicals \\
Nabadweep Chamuah, Lakhi Chetia, \\
Nashrat Zahan et al. \\
- Comparison of diatom records of the \\
$\frac{\text { Heinrich event } 1 \text { in the Western North }}{\text { Atlantic }}$ \\
\hline Isabelle M Gil, Lloyd D Keigwin and \\
Fatima G Abrantes \\
- Hydrofluoric acid-assisted bonding of \\
diatoms with SiOO-based substrates for \\
microsystem application \\
Deyuan Zhang, Junfeng Pan, Jun Cai et \\
al.
\end{tabular}

\section{Recent citations}

- An annual cycle of diatom succession in
$\frac{\text { two contrasting Greenlandic fiords: from }}{\text { simple sea-ice indicators to varied }}$
$\frac{\text { seasonal strategists }}{\text { Tiia Luostarinen } \text { et al }}$
- The distribution and chemical speciation of
$\frac{\text { dissolved and particulate phosphorus in }}{\text { the Bering Sea and the Chukchi-Beaufort }}$
$\frac{\text { Seas }}{\text { Peng Lin et al }}$

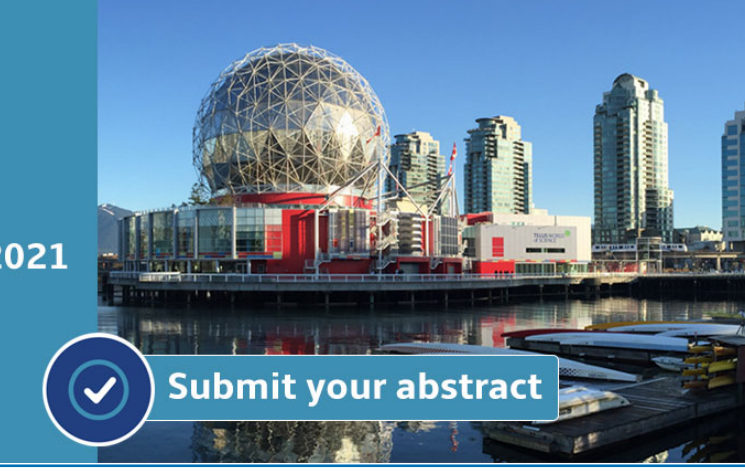




\title{
Marine diatoms in polar and sub-polar environments and their application to Late Pleistocene paleoclimate reconstruction
}

\author{
Xavier Crosta \\ UMR-CNRS 5805 EPOC, Université Bordeaux 1, Avenue des Facultés, 33405 \\ Talence Cedex, France \\ E-mail: x.crosta@epoc.u-bordeaux1.fr
}

\begin{abstract}
Diatoms are one of the major phytoplankton groups in polar and sub-polar marine environments along with green algae and chrysophytes. Diatoms are composed of two components, a two-valve test made of amorphous silica and an organic cell encapsulated into the test. Mucilage covering the test and proteins embedded in the silica lattice of the test completes the organic pool of the diatoms. The preservation of these two components into deep-sea sediments allows for a large set of diatom-based proxies to infer past oceanographic and climatic changes in polar and sub-polar marine environments.

Most diatom species in polar and sub-polar marine environments exhibit a narrow range of ecological preferences, especially in terms of sea-surface temperature and sea ice conditions. Preserved diatom assemblages in deep-sea sediments mirror the diatom assemblages in the phytoplankton. It is subsequently possible to extrapolate the relationships between diatom assemblages in surface sediments and modern parameters to down-core fossil assemblages to document past changes in sea-surface temperatures and sea ice conditions. Congruent analysis of biogenic silica and organic carbon and stable isotope ratios $(\mathrm{O}, \mathrm{Si}$ in the silica matrix and $\mathrm{C}$, $\mathrm{N}$ in the diatom-intrinsic organic matter) provides information on siliceous productivity, nutrient cycling and water mass circulation. Measurements of diatom biomarkers give complementary information on sea ice conditions and siliceous productivity.
\end{abstract}

\section{The diatoms}

\subsection{Classification of diatoms}

Diatom comes from the Greek diatomos, which means 'cut in two' or 'cut in half'.

Diatoms are unicellular organisms in which the cell is encapsulated in an amorphous silica box, called the frustule, composed of two intricate valves (the larger one is called the epivalve and the smaller one the hypovalve). Diatom size varies from $2 \mu \mathrm{m}$ to $1-2 \mathrm{~mm}$. Diatoms belong to the class Bacillariophyceae, in which two orders were defined based on the shape of the frustule: Centrales (round diatoms) and Pennales (elongated diatoms). The Order Centrales is divided in three suborders, each characterized by the shape of the cells, the polarity and the arrangement of the processes. The Order Pennales is divided in two suborders, one including diatoms with a raphe (an elongated slit or pair of slits through the valve wall), the other one including diatoms without a raphe [1]. 
The frustule is highly ornamented with processes (labiate, strutted, internal or external, with or without extensions), pores (areolae), costae, spines, horns, setae and other distinguishing features. Diatom taxonomy is historically based on the morphological characteristics and ornamentation of the frustule [2]. Diatom taxonomy is in constant re-evaluation since the emergence of electronic microscopes and genetic techniques. It is worth noting that paleoceanographers using diatoms are limited to differentiation based on the light microscope.

\subsection{Biology of diatoms}

Diatoms mostly reproduce through vegetative division at a rate of $0.1-8$ times per day [3]. Vegetative reproduction involves the formation of two new hypovalves in the parent diatom's frustule, which progressively leads to reduce the average size of the diatom population. At a given threshold, physiologically dictated, diatoms undergo sexual reproduction through gamete fusion and the formation of an auxospore that renews a full-sized vegetative cell [4]. Size diminution continues in diatoms that did not reproduce sexually until they eventually die.

Some species have another particular stage, the resting spore, which is formed under unfavorable conditions (depleted nutrient levels, low light levels, etc...) and allows the diatom to survive until better conditions return. In the polar marine environment, resting spores allow the diatom population to survive the polar winter and are an important inoculum for spring/summer blooms [5].

\subsection{Ecology of diatoms}

About 285 genera and 12000 species of diatoms have been identified [2] although these numbers are in constant evolution. Diatoms are found in almost every aquatic environment, including fresh and marine waters. Diatoms are also found in aerophilic environments, such as moss banks. Diatoms are photosynthetic organisms possessing yellow-brown chloroplasts with pigments including chlorophyll a and $c, \beta$-carotene, fucoxanthin, diatoxanthin and diadinoxanthin that enable them to capture a wide range of wavelengths and some species are able to live at very low light levels [6]. Most diatoms are non-motile though raphid species use mucilage secretion along their raphe for motility. Diatoms are restricted to the photic zone. In the open marine environment, diatoms are generally planktonic, although some benthic or pseudo-benthic species attached to macro-algae or sea-ice are also encountered.

In the world ocean, diatoms mainly thrive in cold, nutrient-rich regions where silicic acid is not limiting, such as polar regions as well as upwelling systems and coastal areas. In other regions, diatoms are outcompeted by carbonate and organic organisms that have lower nutrient requirements.

At the regional scale, many factors interact to determine the distribution of planktonic diatoms. In polar and sub-polar areas, the most important factors are sea-surface temperatures, sea-ice conditions, macro- and micronutrient levels, stability of the surface water layer, light levels, and grazing. Salinity may also exert a major role on diatom distribution, especially in coastal regions of the Artic Ocean where there is a strong freshwater input from major rivers.

\subsection{From production to burial}

In polar oceans, $1-10 \%$ of the diatoms produced in surface waters reach the sediment [7]. This ratio is higher in shallow coastal areas than in abyssal open ocean regions. Biotic factors such as sedimentation type (single particles vs aggregates or fecal pellets, mass sedimentation events) and abiotic factors such as lateral transport and dissolution in the water column and at the water-sediment interface are the main processes determining the diatom flux to the sea-floor. These processes not only favor the preservation of highly silicified diatoms but also alter the geochemical signals embedded into the diatoms. It has however been shown that the residual sedimentary assemblages are still indicative of surface conditions in different oceanic regions such as the North Pacific [8], the Southern Ocean [911] and the northern North Atlantic [12]. Diatoms can therefore be used to infer past oceanographic and climatic changes in these regions. 


\section{Diatoms as paleoceanogrpahic tools}

Due to the specificity of diatom morphology (organic matter attached and embedded into the siliceous frustule) and ecology, diatoms can be used in various ways to infer past oceanographic conditions including methods based on micropaleontology (diatom identification), geochemistry (biogenic content, organic biomarkers) and isotope geochemistry (either in the diatom-intrinsic organic matter or the siliceous matrix).

\subsection{Micropaleontology}

2.1.1. Rationale.In polar oceans, diatom distribution in phytoplankton presents strong zonations [1315] and diatom distribution in surface sediments presents similar zonations [16-18]. Processes responsible for the production and zonation of diatoms in phytoplankton and export and preservation of diatoms in marine sediments are briefly described in the previous paragraphs. In summary, it is possible to draw direct relationships between diatom assemblages in surface sediments and modern parameters, such as for example sea-surface temperatures (SST) and sea ice duration/concentration (SIP). It is then possible to extrapolate the relationships observed between diatom assemblages in surface sediments and modern parameters to down-core fossil assemblages in order to document past changes in oceanography, in siliceous productivity and, ultimately, in climate. Though our understanding of diatom ecology is based on investigations of diatom distribution in phytoplankton and sediment traps, it is important to note that paleoceanographic reconstructions are based on altered sedimentary diatom assemblages. It is therefore essential to document and quantify the relationships that exist between diatom distribution in surface sediments and environmental parameters as a preliminary step to any paleoceanographic study.

The hypothesis linking diatom assemblages in fossil down-core sediments and surface parameters is called actualism. A given diatom assemblage is produced, and preserved, under specific modern conditions. If the same assemblage is found down-core, then oceanographic and climatic conditions may have been the same in the past as they are today. As such, the use of diatom assemblages to reconstruct past climate variability is more straightforward for recent times when modern species were extant than for older periods when species that are extinct today were an important component of the diatom assemblages.

Diatom identification has been heavily used in polar regions to reconstruct several parameters over the last 40-50 million years: sea-surface temperature [19, 20], sea ice cover [21, 22], siliceous productivity [23, 24], ocean circulation [25] and relative sea level [26]. Diatom identification is also widely used for biostratigraphy $[27,28]$. Investigations can be based on down-core variations of given species of known ecology or on statistical methods that approximate the relationships between modern species and their ecological preferences. As such, transfer functions can provide quantitative estimates of surface properties (SST and sea ice conditions in polar regions) that are essential to constrain or verify paleoclimatic models.

A transfer function must be understood as any kind of mathematical approach that analyses census counts of fossil assemblages to produce absolute values of surface properties by comparing fossil samples to a subset of modern samples having definite modern conditions. Transfer functions can work on reduced species data sets, but transfer functions applied to marine diatom from polar environments generally work with 20-40 species. Diatom-based transfer functions in the marine polar realm are mainly dedicated to the reconstruction of SST and SIP though it is also possible to estimate sea-surface salinity [29] and sea level [26]. It is worth noting that it is technically possible to infer any variable that has a statistically significant relationship to diatom species distribution. The most common ones are the Imbrie and Kipp Method (IKM) [30], the Modern Analog Technique (MAT) [31], the Weighted Averaging Partial Least Square (WA-PLS) [32], Maximum Likelihood (ML) [33] and the Artificial Neural Network method (ANN) [34, 35]. The General Additive Model (GAM) [36] and the Revised Analog Method (RAM) [37] are variations of the IKM and MAT approaches, respectively. 
Transfer functions work in three steps. First, a calibration data set, consisting of counts of diatom taxa in modern sediments and instrumentally recorded values of environmental parameters at the corresponding locations, is assembled. Second, a mathematical model is developed to quantify the relationship between the environmental variable (parameters) and the census counts. Third, this mathematical model is applied to fossil diatom counts to produce a quantitative estimate of the environmental parameter.

Some points to take into account when developing a transfer function:

- Ubiquitous species presenting no relationship with environmental parameters may not be included in the modern database as they will add noise to the estimate.

- Species that do not account for more than $2 \%$ of the diatom assemblage in one sample of the modern sediments are generally not included in the modern database though there is no theoretical reason to exclude them. However, the mathematics supporting function transfer would not benefit from this additional information as the statistical weights of rare species will be overwhelmed by dominant species.

- Dominant species strongly affect transfer functions that use factor analysis as a starting point. For example, Fragilariopsis kerguelensis accounts for $>60 \%$ of the diatom assemblage in Southern Ocean surface sediments when SST is between $2-7^{\circ} \mathrm{C}$. As a result, IKM approach estimates around $4^{\circ} \mathrm{C}$ over the whole range of highest $F$. kerguelensis relative abundances in the training set (validation of the transfer function to estimate the distribution field of modern parameters). The overwhelming influence of dominant species can be alleviated through normalisation of diatom relative abundances by class ranking [38], logarithmic transformation [39], square root or Hellinger. Dominant species do not impact comparative approaches such as the MAT, for which rare species with low abundances are as equally important as dominant species.

- Mathematical techniques must be used according to the calibration data set. Reduced data sets in terms of number of samples and geographical extent would work better with techniques using factor analysis that calculate a mathematical function between the core-top samples and the parameters, thus coping with the lack of samples. Conversely, large calibration data sets work better with more descriptive techniques such as the MAT.

- Paleoreconstructions might be different (1) for a given mathematical technique depending on the calibration data set and (2) for a given calibration data set depending on the mathematical technique.

More details about transfer function techniques, validation, advantages and disadvantages are presented in [40] and [41].

2.1.2. Application.Reconstruction of past physical parameters (SST and SIP) in the polar oceans is of prime importance for a sound understanding of Earth's internal climate system. Quantification of SST and SIP in the past is also essential to constrain or validate paleoclimatic models. In the Southern Ocean, diatoms are certainly the best proxy to reconstruct these parameters while in the Northern Hemisphere dinocysts and foraminifera can be equally used. As such diatoms can be used alone through investigations of single species abundances or transfer functions that nicely compliment qualitative studies. It is worth noting that, although some discrepancies may exist between diatombased paleoreconstructions of SST and SIP as noted above, much greater differences are generally apparent between diatom-based paleoreconstructions and other microfossil-based transfer functions or with geochemical approaches. I describe below two examples to illustrate these points.

Coupling qualitative and quantitative approaches for sea ice reconstruction. Sea ice is one of the fastest reacting, most seasonal geophysical parameters on the Earth's surface of which the waxing and waning strongly influence the global climate. This seasonal cycle strongly affects high latitude ecosystems, economies and civilizations. It also affects Earth's climate through the transfer of high latitude anomalies to lower latitudes via the atmosphere and the ocean. Over the last several decades, there has been a dramatic reduction in perennial sea ice in the Arctic Ocean [42] and the 
Bellinghausen and Amundsen seas in West Antarctica [43]. It is therefore of prime importance to estimate sea ice dynamics in the past and to map sea ice distribution at key periods such as the Last Glacial Maximum (LGM), the present and the last interglacials. To date, the most extensive dataset for Antarctic sea ice mapping was produced for the LGM in the framework of MARGO project (Multiproxy Approach for the Reconstruction of the Glacial Ocean surface). This study represents also a perfect example of coupling of qualitative and quantitative data.

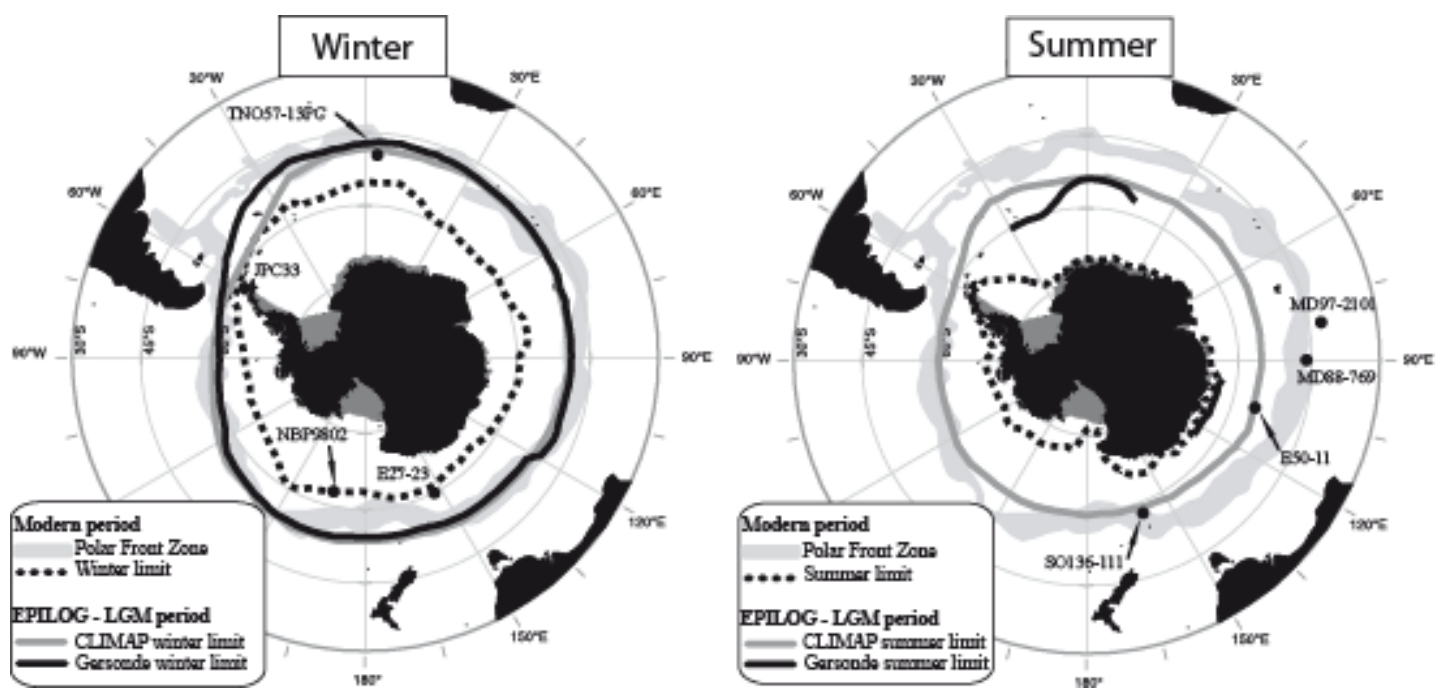

Figure 1. Sea-ice extent at the Last Glacial Maximum during winter and summer seasons in the context of the MARGO program (modified from [45]). Gersonde's winter sea-ice limit was calculated from the F. curta group proxy [44] and the MAT approach [21], while Gersonde's summer limit was estimated from the $F$. obliquecostata proxy [44] and the MAT approach [21]. CLIMAP's winter and summer limits were located at the faunally identified winter and summer $0^{\circ} \mathrm{C}$ isotherms, respectively [46], and lithogenic tracers such as changes in the sedimentation rate, presence of ice-rafted debris and geographical contact between diatom oozes and clayed sediments [50]. Position of the modern sea-ice limits is from Schweitzer [51] and location of the modern hydrographic fronts is from Orsi et al. [52].

Based on extensive investigations of time-series sediment-traps and diatom distribution in surface sediment of the Weddell Sea, Gersonde and Zielinski [44] showed that relative abundances of the Fragilariopsis curta group ( $F$. curta and $F$. cylindrus) greater than $3 \%$ of the total diatom assemblage indicated the presence of winter sea ice. They also showed that relative amounts of Fragilariopsis obliquecostata greater than $3 \%$ indicated the presence of summer sea ice. A combination of the single species proxies described above with a diatom-based transfer function approach (31 species used, Modern Analog Technique [21]) provided a comprehensive picture of winter and summer sea ice cover at the LGM [45]. Diatom assemblages demonstrated that winter sea ice cover at the LGM was twice the modern winter surface while the summer sea ice surface at the LGM was 2-3 times the modern summer surface (Figure 1). These findings greatly refined estimates from CLIMAP [46] in the early 1980s, especially about summer sea ice extent. Indeed, CLIMAP mapped the summer sea ice limit at around $55^{\circ} \mathrm{S}$ in the Atlantic and Indian sectors of the Southern Ocean. But it was demonstrated shortly thereafter that CLIMAP estimated spring sea ice limit rather than summer sea ice limit [47]. When CLIMAP sea ice maps are used as boundary conditions, paleoclimatic models estimate a 80 ppm drop in atmospheric $\mathrm{CO}_{2}$ concentrations [48], while when diatom-based sea ice reconstructions are used, paleoclimatic models estimate a $10-30 \mathrm{ppm}$ drop in atmospheric $\mathrm{CO}_{2}$ concentrations due to sea ice insulation [49]. 
Quantitative approaches for sea-surface temperature reconstructions. Here again, diatom-based transfer functions for SST reconstructions were first developed for the Southern Ocean [38], but rapidly exported for the northern North Atlantic [53]. Diatom-based transfer functions in the Southern Ocean are mainly based on IKM and MAT, while a suite of diatom-based transfer functions have been developed for the North Atlantic. It is worth noting that, there, the new techniques such as WA-PLS and ML did not produce drastically different estimates than IKM [54], either in terms of absolute values or patterns. However, standard errors or Root mean square errors of prediction (RMSEP) were smaller with the new mathematical approaches.

As opposed to the Southern Ocean where diatoms are the main microfossil group for paleoclimatic reconstructions, foraminifera and dinocysts can be used in the northern North Atlantic to estimate SST and SIP. However, diatom-based SST estimates have been produced in many cores from the northern North Atlantic. Diatom-based SST estimates are sometimes rather different than dinocyst-based SST from the same core $[55,56]$, possibly due to their different ecological response or seasonal production. Most diatom-based SST records in the northern North Atlantic are restricted to the Holocene Epoch because of the scarcity of diatoms older than the last deglaciation.

The Holocene is the baseline for recent warming. Understanding the regional heterogeneity of climate changes under different forcings, in a well dated framework, may help to understand the modern and future ocean-atmosphere response. Signal-to-noise rations are smaller during the Holocene Epoch compared to glacial-interglacial cycles and it is necessary to gain insight on how perform transfer functions.

Hereafter is an example on how perform several diatom-based transfer functions applied to a similar down-core diatom dataset. IKM, WA-PLS and ML transfer functions have been applied to diatom assemblages in a sediment core from the Norwegian Sea that covers the last $13 \mathrm{ka}$ BP [54]. The three transfer functions documented a similar SST trend over the last $13 \mathrm{ka}$ BP. Some discrepancies were however apparent between IKM and the two other techniques in terms of the amplitude of changes. IKM estimated warmer summer SST during the Early Holocene and somehow colder summer SST during the Late Holocene with a sharp drop at around 5-4 ka BP. A similar sharp drop in SST was observed in the Southern Ocean at 4 ka BP [57, 58]. WA-PLS and IKM both use several components with an additional step for WA-PLS that maximizes the covariance between the environmental variables to be reconstructed and, hence, the predictive power of the method in contrast to the I\&K method where the components are chosen irrespective of their predictive value to capture the maximum variance within the biological data. The ML transfer function method has no parameters to set, and has the least autocorrelation problems. This transfer function method can be chosen if many of the taxa show a unimodal relationship with the environmental variable of interest [59]. The present example demonstrated that SST estimates are significant, almost irrespective of the transfer function used, when the modern datasets are extended enough to adequately cover the full range of environmental conditions expected in the past.

In the present example, the three reconstructions documented an overall cooling trend (Figure 2), in step with the decreasing insolation in the Northern Hemisphere, indicating a causal impact of orbital forcing on Holocene sea-surface temperatures in the Nordic seas [55]. A focus on the 13-9 ka BP period documented sea-surface temperatures $7-9^{\circ} \mathrm{C}$ colder during the Younger Dryas than today and a rapid warming at $11.7 \mathrm{ka} \mathrm{BP}$ in phase with the warming recorded in Greenland ice cores. The slow warming registered after the sharp transition between the Younger Dryas and the Pre-Boreal Optimum was interrupted by two cooling events attributed to disturbances in the North Atlantic Ocean thermohaline circulation. Superimposed on the general trend, high-amplitude centennial variability was observed in the sea surface temperatures (Figure 1). The variability showed a periodicity of $80-$ 120 years, similar to solar activity periodicities indicating that even small changes in solar irradiance can have a large impact on sea-surface temperatures and ocean circulation [20]. Similar periodicity was identified in relative abundances of sea ice-related diatoms in a sediment core from the Antarctic continental shelf and was similarly attributed to solar activity forcing [58]. 


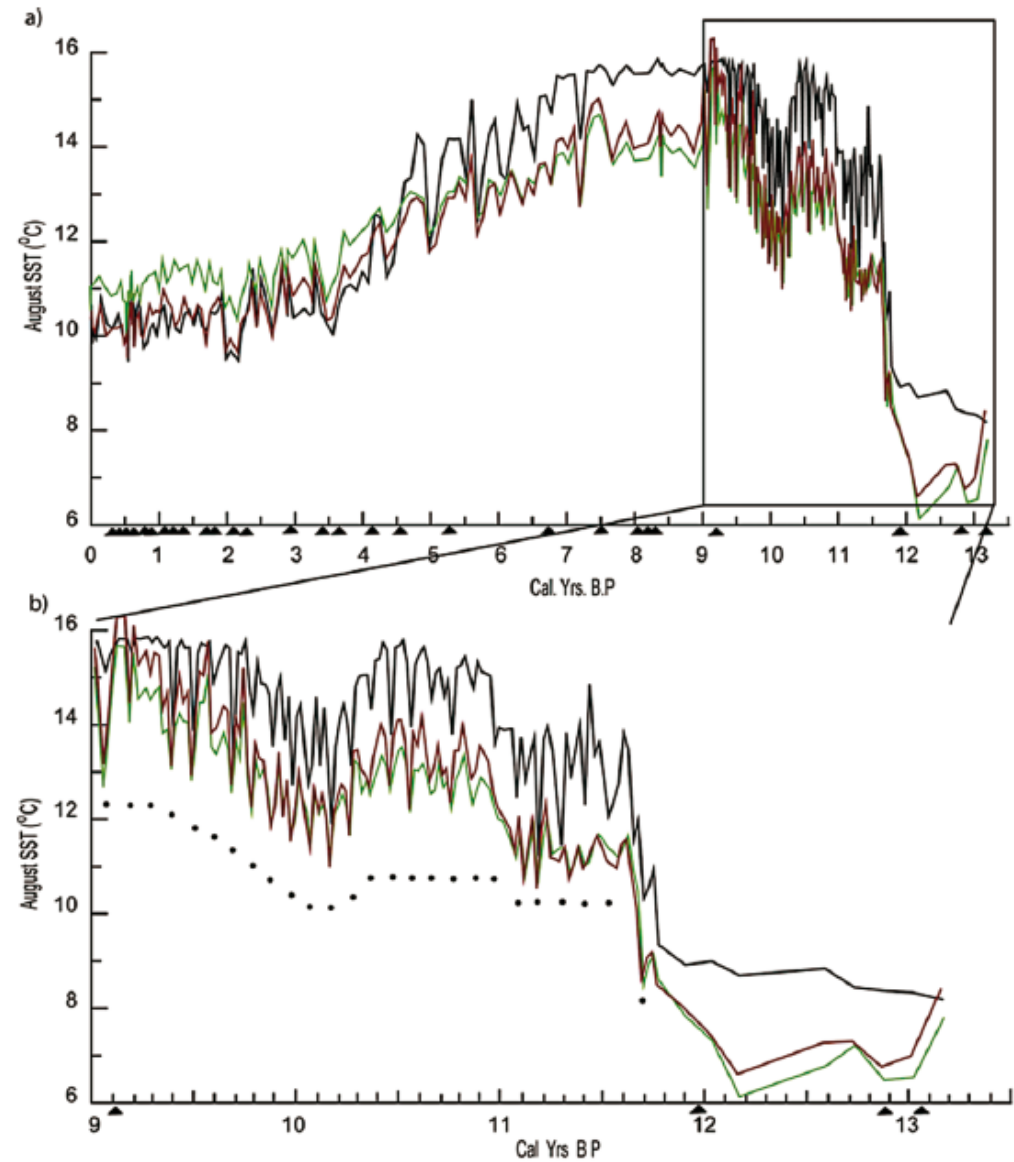

Figure 2. Diatom-based sea surface temperature reconstructions during the last $13 \mathrm{ka}$ (Imbrie and Kipp, black curve; Weighted Averaging Partial Least Square, red curve; Maximum Likelihood, green curve). The period from 13$9 \mathrm{ka}$ BP is shown in details in the lower graph. The black dots denote significant cooling events, while the black triangles represent ${ }^{14} \mathrm{C}$ dating Reproduced with permission from [54] (C) Berner et al., 2010), by permission of SAGE Publications Ltd.

Quantitative approaches for other parameters. Diatom-based transfer functions are more rarely used for sea-surface salinity [29] and relative sea level changes [26] in the northern North Atlantic. This may in part reflect difficulties in developping such transfer functions because of the low signal-tonoise ratio in coastal areas. Indeed, diatom assemblages in coastal areas generally show strong variability, sometime irrespective of salinity and sea level, because of other parameters that are more important in these highly dynamic zones (wind mixing, lateral transport, tides, etc...). However, these transfer functions, if further improved in the future, will give important quantitative data to paleoclimatic models.

\subsection{Geochemistry}

2.2.1. Rationale. Diatoms transfer biogenic silica and organic matter, including species-specific molecules, to deep sea sediments. When dissolution/preservation issues are constrained, it is possible to use geochemical proxies to reconstruct past changes in environmental conditions. The content of biogenic silica and organic carbon in sediments tracks variations in productivity of siliceous organisms [60], which in turn gives information on the oceanic nutrient cycles [61]. Trace element content 
$(\mathrm{Zn} / \mathrm{Si} ; \mathrm{Ge} / \mathrm{Si})$ records changes in surface water salinity and delivery rates of weathering products to the sea from continental and seafloor weathering, respectively [61, 62]. Finally, content in diatomspecific biomarkers (highly branched isoprenoids; long-chain diols), which are synthesized by very few diatom species living in specific habitats, reflect changes in sea ice cover and productivity, respectively $[63,64]$.

In conclusion, diatoms offer a suite of geochemical proxies to compliment diatom census counts and diatom-based transfer functions. Combining these different approaches is essential in regions where other organisms are not well preserved in sediments. Additionally, radiocarbon dating of diatom bound organic compounds allows the replacement of paleoceanographic interpretations from carbonate-barren sediments back into a temporal timescale [65].

\subsubsection{Applications}

Qualitative reconstructions of sea ice conditions. Recently, it has been shown that some diatoms present in Arctic sea ice biosynthesize a specific biomarker, a mono-unsaturated highly branched isoprenoid (HBI) composed of 25 atoms of carbon [63]. A di-unsaturated HBI (Diene) is also synthesized by Arctic sea ice diatoms while isomers with greater number of unsaturation (Triene to Pentaene) are synthesized by phytoplankton diatoms. However it has been shown that the monoeme isomer was the most stable in sediments underneath Arctic sea ice and it was, thus, proposed as a new proxy to infer Arctic spring sea ice. This proxy is referred as IP25 [63]. As a concentration proxy, one has to be careful about dilution of the monoeme by other sedimentary phases (biogenic organisms or terrigenous particles), especially in coastal areas that are prone to material advection and winnowing. Laboratory methods, implying extraction with a solvent, purification of the extract and analysis by GC-MS, are described in Belt et al. [63, 66]. Analyzing HBI content in down-core sediments is much faster than identifying diatom assemblages. However HBIs fail to capture of the environmental details that can be drawn from the identification of dozens of diatom species or species groups.

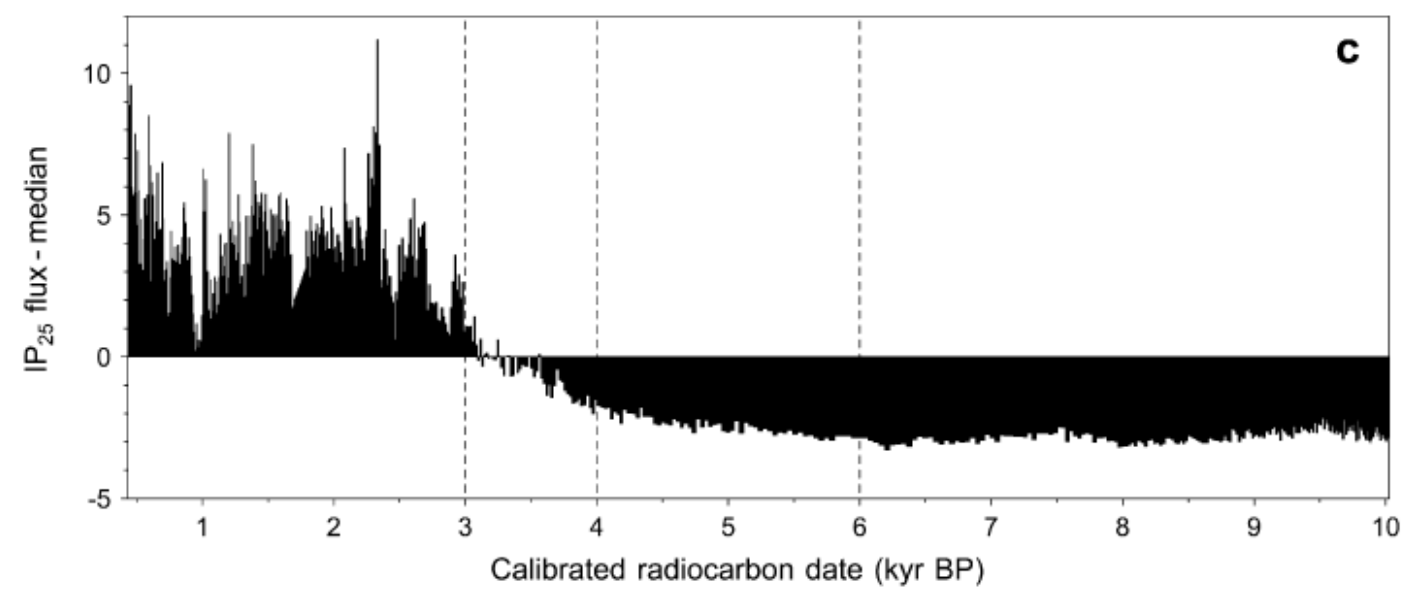

Figure 3. Temporal profile of biomarkers in the ARC-3 core (Canadian Arctic Archipelago) versus time, presented as the difference between IP25 fluxes and the median. Reprinted from [68] with permission from Elsevier.

Several IP25 records have been published in the Arctic realm to date [67, 68]. One of these records from the Canadian Arctic Archipelago demonstrated that spring sea ice was lowest during the early-tomid Holocene, increased slowly between 6-4 ka BP and increased abruptly between 4-3 ka BP to reach a modern, though highly variable sea ice occurrence, at around $2.5 \mathrm{ka} \mathrm{BP}$ (Figure 3) [68].

Diatom HBIs evidenced a similar evolution of the sea-ice cover in the Antarctic realm during the Holocene $[69,70]$, in phase with diatom census counts from the same cores. In the Southern Ocean, sea ice diatoms synthesize a di-unsaturated HBI (Diene) while phytoplankton diatoms synthesize a tri- 
unsaturated HBI (Triene). Environmental interpretations are based on the Diene-to-Triene ratio [71]. It has been suggested that early diagenesis does not affect differently the Diene and Triene, though more work at the seasonal timescale is needed to really determine how the HBI signal is formed and exported from the photic zone and preserved in modern and down-core sediments. The Diene-toTriene ratio is additionally free of any dilution effect. As such, it represents a complimentary and quick proxy to document Antarctic sea ice conditions, interpreted as qualitative yearly sea ice duration. Here again, diatom census counts offer a wider range of paleoenvironmental interpretations.

The transition between a warmer Hypsithermal and a cooler Neoglacial at around 5-4 ka BP has been evidenced globally by other proxies [72], possibly in relation to the disappearance of northern Hemisphere ice sheets [73] and ocean reoganisation [74].

Productivity over the last $30 \mathrm{ka}$. Diatoms play a major role in the export of organic carbon to the deep sea. Studying the factors controlling the contribution of diatoms to total production is pivotal for our understanding of the mechanisms controlling the efficiency of the biological pump of carbon in various regions of today's ocean. Only $1-10 \%$ of the biogenic silica produced in surface waters is eventually preserved in deep-sea sediments. Grazing, dissolution, remineralization, export efficiency and diagenesis strongly alter the surface signal. Nonetheless, it was shown that oceanic zones with high silicic acid content and high siliceous productivity such as the Southern Ocean, the North Pacific and upwelling systems display high biogenic silica in surface sediments [7]. As such, it is believed that down-core biogenic silica content (and more accurately, down-core biogenic silica fluxes) can be used to track past changes in siliceous productivity. Comparison of biogenic content to organic carbon content in deep sea cores opens a new field on diatom physiology changes through time [75, 76]. Comparison of biogenic silica content to stable isotopes measured in diatoms give insight in past nutrient utilization and past oceanic circulation [77, 78].

Diatom biomarkers are an emerging analytic and scientific field to track changes in diatom productivity. Long-chain diols ( 28 and $\mathrm{C} 30)$, biomarkers specifically synthesized by the diatom genus Proboscia, may be used to estimate past changes in nutrient input by Southern Ocean upwelling [64].

The two examples below highlight how diatom-based organic geochemistry can give information on productivity changes during the last 30 kans. Obviously, the biogenic silica proxy has been applied to much older sediments to represent siliceous productivity changes over the geological time scale in relation to major oceanographic reorganizations $[79,80]$. Examples were here chosen to fit the Late Pleistocene glacial-interglacial timescale.

The Southern Ocean is one of the largest High-Nutrient, Low-Chlorophyll (HNLC) regions of the world in which low concentrations of trace metals, such as iron, limit primary productivity. The North Pacific is also a HNLC region, though iron input is greater than in the Southern Ocean because the latter one has less proximal continents [81]. Today, high productivity (mainly diatoms) is found south of $50^{\circ} \mathrm{S}$ between the Antarctic Polar Front and the winter sea ice edge due to the upwelling of deep waters that brings nitrate and silicic acid to the surface waters [82]. High productivity is also encountered in Antarctic coastal areas where iron limitation is alleviated [83].

Analysis of opal content in three cores from the three sectors of the Antarctic Ocean demonstrated a large increase in opal fluxes during the deglaciation (Figure 4). A concomitant increase in ${ }^{231} \mathrm{~Pa} /{ }^{230} \mathrm{Th}$ ratios indicate that these greater opal fluxes did not result from changes in preservation but reflect changes in opal production as a result of a more intense upwelling [23]. Both ${ }^{231} \mathrm{~Pa}$ and ${ }^{230} \mathrm{Th}$ are produced uniformly by radioactive decay of dissolved uranium. Both isotopes are removed from seawater by scavenging. However, ${ }^{231} \mathrm{~Pa}$ has a strong affinity to sorption to biogenic opal particles while ${ }^{230} \mathrm{Th}$ has a more even affinity for sorption to any sinking particle. As such, ${ }^{231} \mathrm{~Pa} /{ }^{230 \mathrm{Th}}$ ratios of particulate material throughout the global ocean are positively correlated with the opal content of particles. Particulate ${ }^{231} \mathrm{~Pa} /{ }^{230} \mathrm{Th}$ ratios are not impacted by loss of biogenic phases during diagenesis. Downcore records of particulate ${ }^{231} \mathrm{~Pa} /{ }^{230 \mathrm{Th}}$ can thus be interpreted in terms of past changes in opal fluxes. In the present example, the positive correlation between ${ }^{231} \mathrm{~Pa} /{ }^{230 \mathrm{Th}}$ and opal fluxes indicates 
that deglacial maximum in opal flux reflected changes in opal production and silicic acid supply rather than variable opal preservation.

However, the balance between greater opal and organic carbon production (drawdown) and greater upwelling (outgassing) resulted in greater atmospheric $\mathrm{CO}_{2}$ concentration demonstrating a direct link between ventilation of the deep Southern Ocean and atmospheric $\mathrm{CO}_{2}$ concentrations [84].

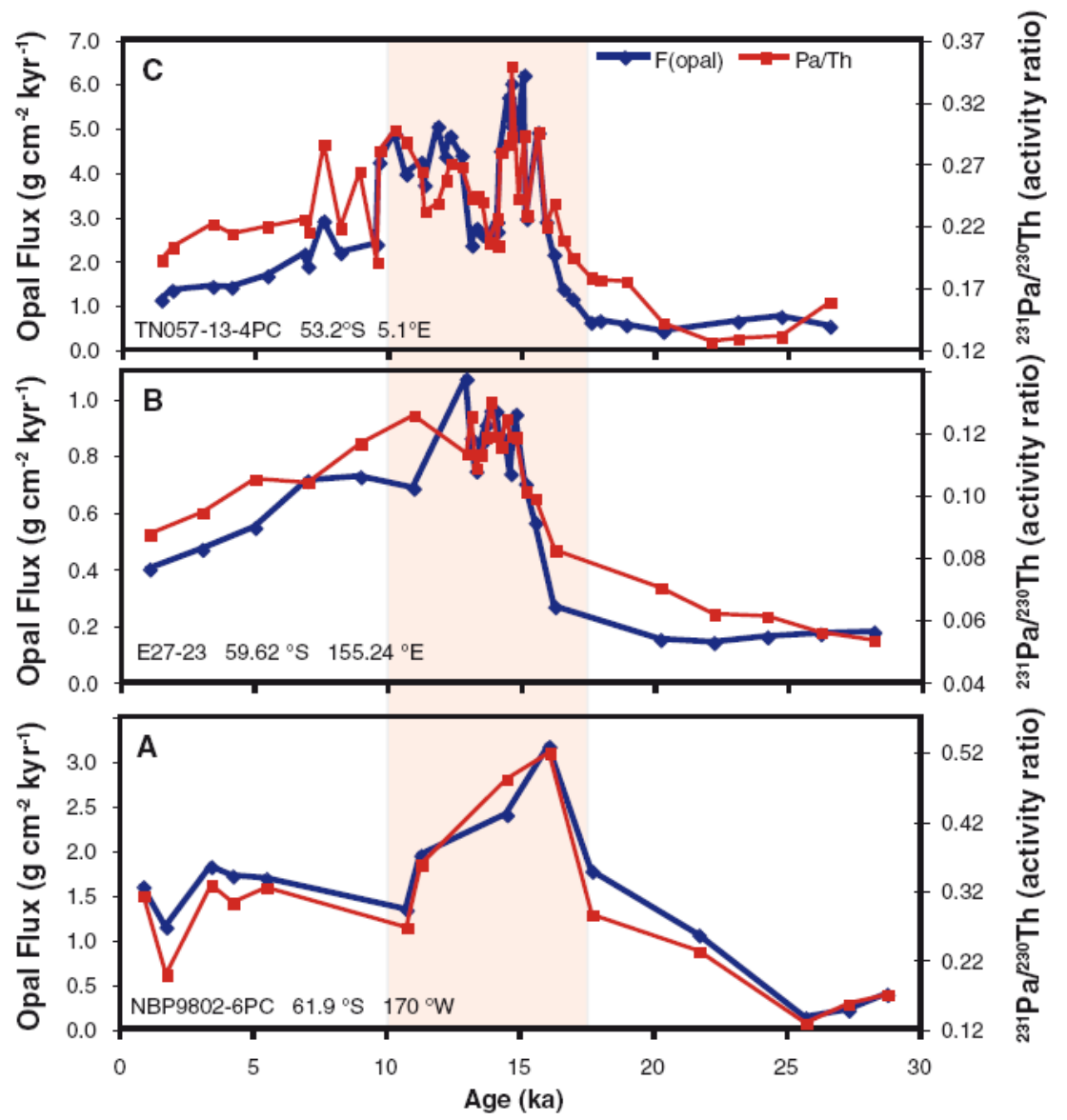

Figure 4. Opal fluxes from three sites in the Southern Ocean. The shaded box highlights the period of maximum export productivity. Initial unsupported ${ }^{231} \mathrm{~Pa} /{ }^{230} \mathrm{Th}$ ratios mirror the pattern of opal fluxes, supporting the idea that the opal fluxes reflect changes in opal production rather than in opal preservation. From [23]. Reprinted with permission from AAAS. Location of the cores in Figure 1.

Following the authors' argument, the decrease in opal fluxes and ${ }^{231} \mathrm{~Pa} /{ }^{230 \mathrm{Th}}$ ratios since $10 \mathrm{ka} \mathrm{BP}$ (Figure 4) would indicate a reduction in Southern Ocean upwelling intensity during the Holocene. These results are at odds with investigations from the Antarctic coastal area. Indeed, although overall productivity decreased during the Holocene in Antarctic coastal areas (Figure 5a,b), long-chain diols and diatom counts demonstrated enhanced intrusion of Modified Circumpolar Deep Waters to coastal areas (Figure 5c). Long-chain diols are synthesized by Proboscia species that thrive in turbulent, nutrient-rich surface waters as evidenced both in Antarctica [64] and the Arabian Sea [85]. These studies indicated that long-chain diols can be used as proxies for high nutrient conditions. Therefore the diol index record from the Antarctic Peninsula showing a strong increase at around $4 \mathrm{ka} \mathrm{BP}$ (Figure 5c) suggest a congruent increase in turbulence and nutrient input to surface water and, thus, an increase in upwelling of Modified Circumpolar Deep Waters. Similar increase in upwelling of 
Modified Circumpolar Deep Waters was suggested in East Antarctic coastal area based on sedimentological and diatom census counts proxies [24].

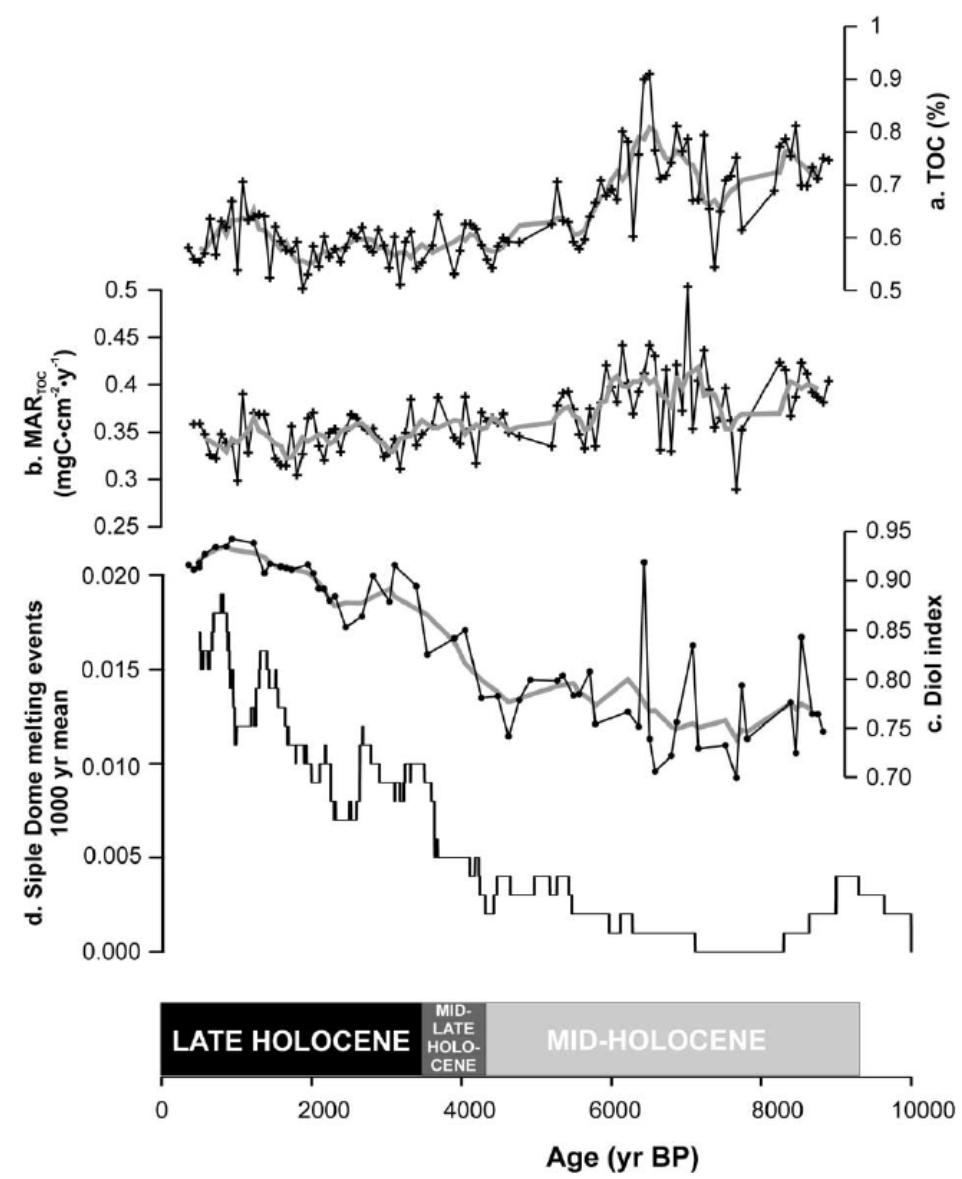

Figure 5. Antarctic climate records of a. TOC content of JPC-33 core, and b. Mass accumulation rates of TOC (MARTOC) reflecting general productivity. c. Long-chain diol index of JPC-33 core reflecting Proboscia diatom productivity. d. Melt frequency observed at Siple Dome ice core (after Das \& Alley 2008). Dark grey lines in $\mathbf{a}, \mathbf{b}$, and $\mathbf{c}$ represent running average with a $10 \%$ smoothing window (position of the core in Figure 1). From [64].

Two possible explanations may reconcile the apparent paradox of lower upwelling in southern hemisphere mid- and high latitudes. First, the core of Southern Ocean upwelling moved southward during the Holocene in phase with the poleward migration of the Westerlies [86]. As a result, less nutrients were brought to the Polar Front Zone area. Second, paleoproductivity (understood as export and burial of organic carbon and silica) was decoupled from nutrient input and resulted from greater export of larger diatoms. It is worth noting that $\delta^{15} \mathrm{~N}_{\text {diat }}$ and $\delta^{30} \mathrm{Si}$ records do not show any special feature (a peak demonstrating greater nutrient utilization or a low suggesting greater nutrient input) during the deglaciation when the peak in opal flux is recorded [76, 77, 78, 87, 88].

\subsection{Isotope geochemistry}

2.3.1. Rationale.It is possible to analyze stable isotopic ratios of light elements in diatoms to track changes in surface water properties. Several different and complementary isotopes can be measured in 
diatoms. Two groups of isotopes detected in diatoms can be differentiated: firstly, oxygen $(\mathrm{O})$ and silicon $(\mathrm{Si})$ isotopes that are carried by the diatom frustule and, secondly, carbon $(\mathrm{C})$ and nitrogen $(\mathrm{N})$ isotopes that are carried by the organic matrix. This organic matrix, called diatom-intrinsic organic matter (DIOM), is intimately embedded in the silica lattice where it directs opal biomineralization. Analyzing DIOM rather than bulk organic matter provides a more direct picture of surface water nutrient cycling because the DIOM is protected from remineralisation and diagenesis by the silica matrix. $\delta^{18} \mathrm{O}$ provides information on the water masses, $\delta^{30} \mathrm{Si}$ and $\delta^{15} \mathrm{~N}$ on nutrient cycling (as a balance between supply and uptake) and $\delta^{13} \mathrm{C}$ on nutrient cycling and, in given conditions, on $\mathrm{CO}_{2}$ exchange at the ocean-atmosphere interface.

Measurements of $\delta^{18} \mathrm{O}_{\text {diatom }}$ reflect the isotopic composition of the ambient seawater, which is a function of changes in global ice volume as well as local changes in evaporation, freshwater inputs, salinity and changes in water mass or ocean circulation, the temperature of the water in which the diatom is precipitated and the presence of any isotope vital effects that may exist in diatoms. Measurements of $\delta^{18} \mathrm{O}_{\text {diatom }}$ are representative of changes in the photic zone [89]. Measurements of $\delta^{18} \mathrm{O}_{\text {diatom }}$ were successfully used to track iceberg melting events in the Southern Ocean [90, 91].

The $\delta^{15} \mathrm{~N}$ of sinking organic matter reflects the utilization of nitrate in regions where nitrate is not completely consumed [92]. Phytoplankton preferentially takes up ${ }^{14} \mathrm{~N}$-bearing $\mathrm{NO}_{3}^{-}$. As the initial $\mathrm{NO}_{3}{ }^{-}$supply is progressively consumed, the $\delta^{15} \mathrm{~N}_{\text {nitrate }}$ increases, leading to a related increase in the $\delta^{15} \mathrm{~N}$ of the organic matter produced from the $\mathrm{NO}_{3}{ }^{-}$. The $\mathrm{N}$ isotopic composition of the surface $\mathrm{NO}_{3}{ }^{-}$ pool and surface sedimentary organic matter were shown to reflect the proportion of the $\mathrm{NO}_{3}{ }^{-}$supply from the subsurface that is consumed in the euphotic zone. Enriched $\delta^{15} \mathrm{~N}$ values thus indicate enhanced nitrate relative utilisation.

The same principle and interpretation are applicable to silicon stable isotopic ratios in which enriched $\delta^{30} \mathrm{Si}$ values reflect enhanced silicic acid relative utilisation in surface waters $[87,93]$.

\subsubsection{Applications}

Productivity and nutrient cycling in the Southern Ocean over the last $30 \mathrm{ka}$

Nitrogen and silicon stable isotopic ratios measured in diatoms track nutrient relative utilization as a balance between supply (mainly upwelling in the Southern Ocean) and uptake (mainly by diatoms in the Southern Ocean). As such, the important changes in biogenic burial evidenced during deglaciation and the inferred increase in upwelling [23] should be seen in the $\delta^{15} \mathrm{~N}_{\text {diat }}$ and $\delta^{30} \mathrm{Si}$. However, no $\delta^{15} \mathrm{~N}_{\text {diat }}$ and $\delta^{30} \mathrm{Si}$ investigations from the Antarctic part of Southern Ocean show any significant changes during the 10-15 ka BP (e.g., Figure 6). Important changes in the isotope data occurred prior to the peak in opal. Only records from the Subantarctic to Subtropical zones evidenced a possible concomitant peak in $\delta^{15} \mathrm{~N}_{\text {diat }}$ (Figure 6, right box) [94]. As such $\mathrm{N}$ and $\mathrm{Si}$ isotopes are not very supportive of enhanced productivity and upwelling in the Antarctic realm between 15-10 ka BP.

$\delta^{15} \mathrm{~N}_{\text {diat }}$ and $\delta^{15} \mathrm{~N}_{\text {bulk }}$ records from the Antarctic Ocean demonstrated a Holocene pattern toward lighter values (Figure 6) [25] demonstrating a reduction in relative nutrient utilization, in phase with decreasing productivity but increasing upwelling in coastal areas [65].

Coupling nitrogen and silicon isotopes in the same records may help to draw some interpretations about changes in diatom physiology. Such changes need to be taken into account to better understand the relationships between productivity and nutrient input.

Iron content in surface waters has a strong impact on diatom physiology. Laboratory experiments have shown that uptake ratios of $\mathrm{N} / \mathrm{Si}$ and $\mathrm{C} / \mathrm{Si}$ by diatoms are greater when iron is not limiting [95, 96]. Disregarding potential modification of the nitrate-to-silicic acid supply ratio by the upwelling of Circumpolar Deep Water, anti-correlated $\delta^{15} \mathrm{~N}_{\text {diat }}$ and $\delta^{30} \mathrm{Si}$ records argue for different relative uptake of nitrate and silicic acid through time, with greater uptake of nitrate during the last glacial and greater uptake of silicic acid during the Holocene (Figure 6). These changes are in agreement with the dust concentration record of Vostok, indicating a potential role of iron deficiency alleviation on diatom physiology during glacial times. However, differential nutrient uptake between warm and cold times 
was not transferred to the Subtropical Zone as little change in $\delta^{15} \mathrm{~N}_{\text {diat }}$ and $\delta^{30} \mathrm{Si}$ is recorded at the SSTF (and out of phase with the climatic periods). It is possible that Antarctic Surface Waters sank and were transported northward as Antarctic Intermediate Waters to ultimately fuel low latitude systems. This hypothesis, called the Silicic Acid Leakage Hypothesis, may explain a $40 \mathrm{ppm}$ decrease in atmospheric $\mathrm{CO}_{2}$ concentrations [97], which is almost half of the glacial drop.
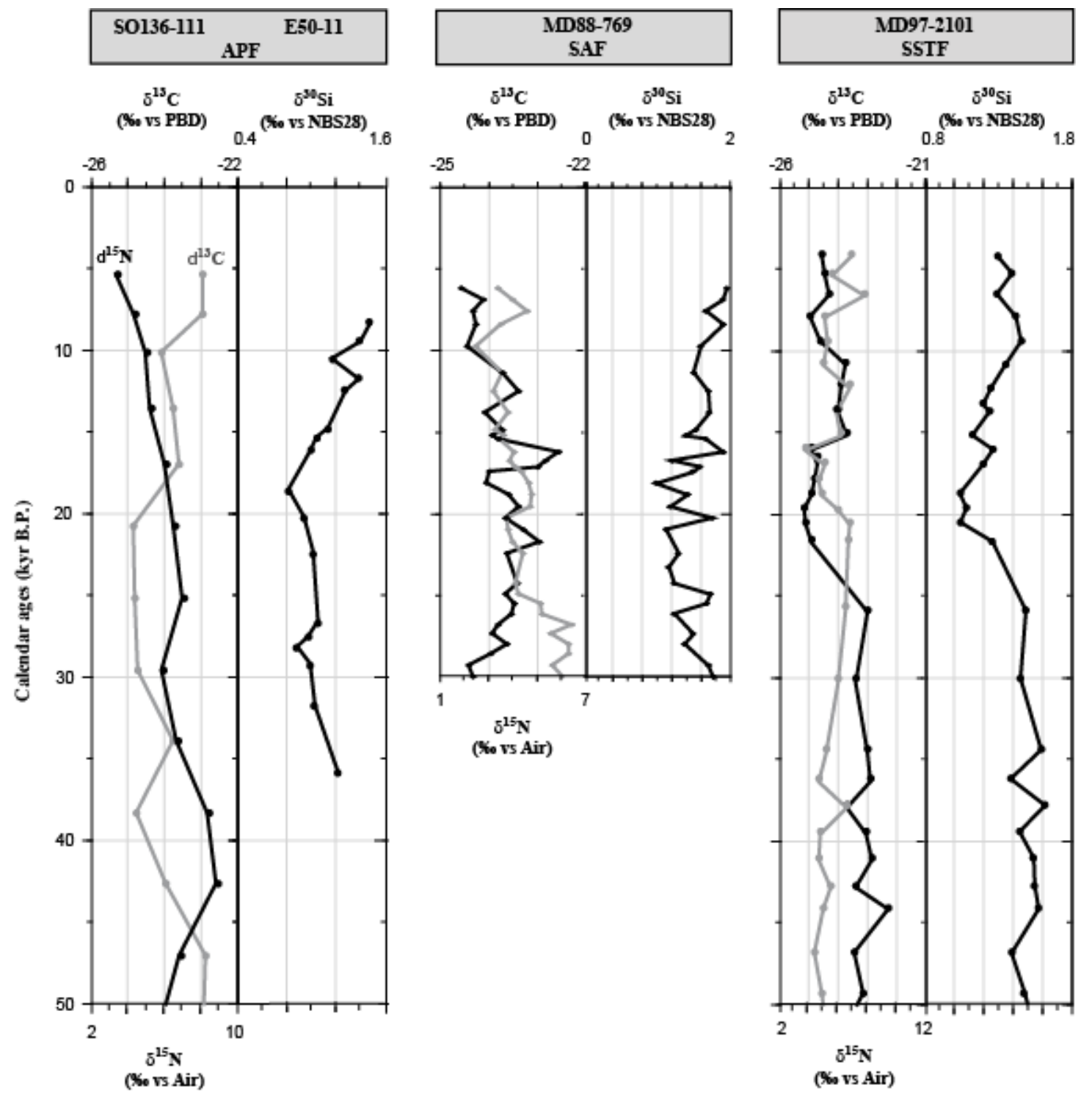

Figure 6. Carbon, nitrogen and silicon isotopes in diatoms versus age from the Antarctic Polar Front Zone (APF), the Subantarctic Front (SAF) and the Southern Subtropical Front (SSTF) in the Indian sector of the Southern Ocean [78, 87, 98]. Reprinted from [41], with permission from Elsevier. Location of the cores in Figure 1.

Productivity and nutrient cycling in the North Pacific over the last $30 \mathrm{ka}$. Similar to the Antarctic Ocean, large regions of the the subarctic North Pacific are today characterized by high phytoplankton productivity and incomplete consumption of the major nutrients in surface waters. Investigation of deep-sea cores have, however, demonstrated that, during much of the last ice age, biological export production in the subarctic Pacific, including the Bering and Okhotsk Seas, was considerably lower than during the Holocene (Figure 7, upper box) [99]. The pattern of DIOM- $\delta^{15} \mathrm{~N}$ record is opposite to 
the opal record with enriched values during the last glacial when opal content was low and depleted values during the Holocene when opal content was high (Figure 7). A constant pool of nutrient over the considered period would have been conducive to depleted $\delta^{15} \mathrm{~N}_{\text {diat }}$ values during the last glacial and enriched $\delta^{15} \mathrm{~N}_{\text {diat }}$ values during the Holocene. The observed anti-correlation between opal content and $\delta^{15} \mathrm{~N}_{\text {diat }}$ over the last $30 \mathrm{ka}$ suggested a reduced supply of nitrate to the surface due to stronger stratification of the upper water column of the Bering Sea during glacial times, possibly in relation to greater sea ice extent such as inferred in the Southern Ocean [100]. The reduction of the nutrient pool during glacial time yielded to a more complete consumption of nitrate and therefore enriched $\delta^{15} \mathrm{~N}_{\text {diat }}$.

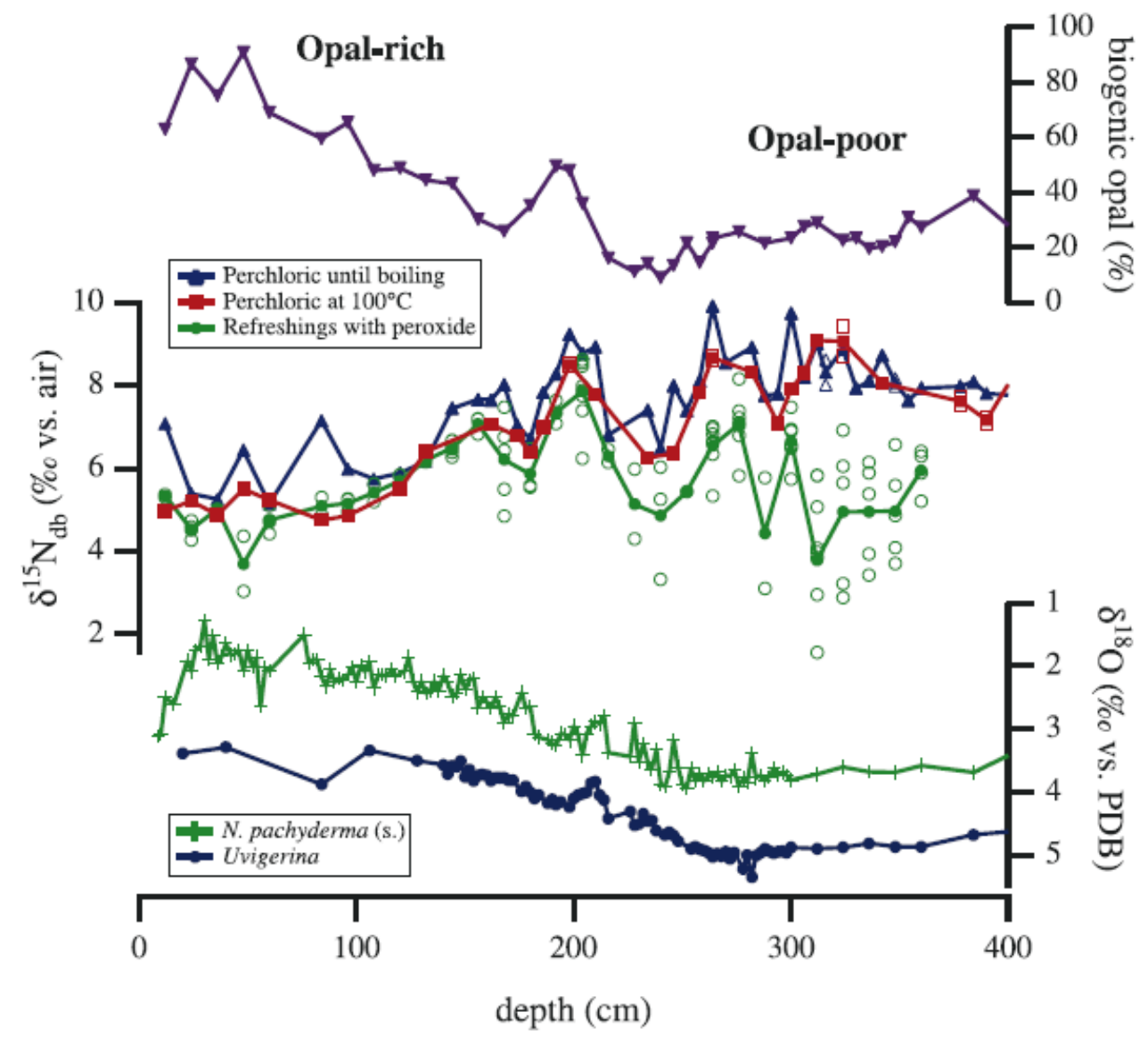

Figure 7. Records of biogenic opal, $\delta^{15} \mathrm{~N}_{\text {diat }}$ and $\delta^{18} \mathrm{O}_{\text {foram }}$ in a core from the Bering Sea [99]. The last glacial period covers the $400-270 \mathrm{~cm}$ interval, the last deglaciation covers the $270-150 \mathrm{~cm}$ interval, and the Holocene covers the $150-0 \mathrm{~cm}$ interval. Copyright 2007 American Geophysical Union. Reproduced by permission of American Geophysical Union.

\section{Summary and future developments of the diatom tool}

Diatom identification provides unique environmental reconstructions on sea-surface temperatures, sea ice, salinity and productivity. Diatom census counts have long been used to infer such past oceanic conditions. We are however far from fully understanding this proxy as very few studies monitored diatom production in the phytoplankton, diatom export and preservation in deep-sea sediments over multi-annual time series [101, 102]. It is necessary to better understand diatom ecology when considering shorter spatial and temporal timescales as other factors than large scale parameters may 
play a significant role on diatom distribution. Multi-annual survey of diatom distribution in phytoplankton and modern sediments is however difficult in polar areas because of logistic issues.

Diatom identification under a light microscope is very time consuming, especially when diatom preservation is poor or when dilution by terrigenous particles is high. As such, one of the next challenges is to develop automated methods for the identification and biometry of diatoms, such as done for palynomorphs [103], coccolithes [104] and foraminifera [105]. An early step was recently done in this direction. An automated imaging and characterization system with computer-controlled transmitted light microscopy adapted to diatom specificities is currently in development [106].

More developments will certainly concern geochemistry. Currently, a great effort is been made to obtain reliable radiocarbon dates from the organic compounds intrinsic to diatom frustules (Ingalls et al., 2004), in order to help in dating sediments devoid of foraminifera. More work is needed to better understand the formation of the isotope signals in diatoms. It is essential to better constrain vital effects that dictate isotopic fractionation factors [107-109], nutrient sources and metabolite pathways $[110,111]$ and alteration of the signal formed in the phytoplankton during settling and burial [92, 112]. More work is also needed to develop new protocols that allow for accurate and rapid measurement of stable isotopes in diatoms [113-115]. To date, very few records of $\delta^{30} \mathrm{Si}$ exist, all of them at multi-millennial scales, partly because of the tedious protocol. Diatom-specific biomarkers will certainly represent the greatest advancement in diatom research in the next decade. However, work is needed to identify precisely which species synthesize HBIs. Mono- and di-unsaturated HBIs are synthesized by some sea ice diatoms such as Haslea spp., which represent a minor component of both Arctic and Antarctic sea ice diatom communities [63], while tri- to penta-unsaturated are synthesized by open ocean diatoms such as Rhizosolenia spp. Little is known about the role of HBIs in the diatoms. Similarly, long-chain diols are synthesized by Proboscia spp. [64], which can represent a significant part of open ocean diatom communities [116]. Here again, little is known about the role of long-chain diols in diatom physiology. It is therefore essential to better understand which species form HBIs or diols, in which conditions, when in the year, and how the molecules are exported and preserved in sediments to refine the interpretations based on these proxies. It is worth noting that the sea ice diatoms synthesizing mono- and di-unsaturated are very seldom found in sediments. With this understanding, the coupling of diatom-biomarkers and diatom census counts will be much more effective and will, maybe, give insight on sea ice seasonality in that sea ice HBIs are thought to be formed during early spring while diatom counts are thought to infer yearly sea ice presence.

\section{References}

[1] Simonsen R 1979 Bacillaria 29

[2] Round F, Crawford R and Mann D 1990 The Diatoms (Cambridge: University Press) 747 p

[3] Smetacek VS 1985 Mar. Biol. 84239

[4] Round F 1972 Nova Hedwigia 23291

[5] Horner R 1985 Sea Ice Biota (Boca Raton FL: CRC Press) 83

[6] Kemp AES 2000 Deep-Sea Res. II 472129

[7] Ragueneau O et al. 2000 Globa Planet. Change 26317

[8] Sancetta C 1992 Paleoceanography 7(2) 183

[9] Armand L, Crosta X, Romero O and Pichon JJ 2005 Palaeogeogr. Palaeoclimatol. Palaeoecol. 22393

[10] Crosta X, Romero O, Armand L and Pichon JJ 2005 Palaeogeogr. Palaeoclimatol. Palaeoecol. 22366

[11] Romero O, Armand L, Crosta X and Pichon JJ 2005 Palaeogeogr. Palaeoclimatol. Palaeoecol. 22349

[12] Koç-Karpuz N and Schrader H 1990 Paleoceanography 5(4) 557

[13] Hasle GR 1969 Hvalradets Skrifter 52168 p

[14] Simonsen R 1974 Meteor Forsch.-Ergeb. Reihe D19 1

[15] Semina HJ 2003 Iconographia Diatomologica 101 
[16] Defelice DR and Wise SW 1981 Mar. Micropaleontol. 629

[17] Sancetta C 1982 Micropaleontology 28(3) 221

[18] Zielinski U and Gersonde R 1997 Palaeogeo. Palaeoclim. Palaeoecol. 129213

[19] Schneider-Mor A, Yam R, Bianchi C, Kunz-Pirrung M, Gersonde R and Shemesh A 2005 Geophys. Res. Let. 32 doi: 10.1029/2005GL022543

[20] Jiang H, Eiricksson J, Schulz M, Knudsen K and Seidenkrantz M 2005 Geology 33(1) 73

[21] Crosta X, Pichon JJ and Burckle L 1998 Paleoceanography 13(3) 284

[22] Justwan A and Koç N 2008 Mar. Micropaleontol. 66264

[23] Anderson R, Ali S, Bradtmiller L, Nielsen S, Fleisher M, Anderson B and Burckle L 2009 Science 3231443

[24] Denis D et al. 2009a Quat. Sci. Rev. 28(13-14) 1291

[25] Denis D et al., 2009b Paleoceanography 24 doi: 10.1029/2008PA001689

[26] Woodroffe S and Long A 2010 Quat. Int. 221(1-2) 91

[27] Koç N and Scherer R 1996 Proc. Ocean Drill. Prog., Scient. Results 15161

[28] Zielinski U and Gersonde R 2002 Mar. Micropaleontol. 45225

[29] De Sève MA 1999 Mar. Micropaleontol. 36249

[30] Imbrie J and Kipp N G 1971 The Late Cenozoic Glacial Ages ed K K Turekian (New Haven: Yale University Press) 71

[31] Hutson WH 1980 Science 20764

[32] ter Braak CJF and Juggins S1993 Hydrobiologia 269-270 485

[33] Birks CJA and Koç N 2002 Boreas 31(4) 323

[34] Malmgren BA and Nordlund U 1997 Palaeogeogr. Palaeoclimatol. Palaeoecol. 136359

[35] Malmgren BA, Kucera M, Nyberg J and Waelbroeck C 2001 Paleoceanography 16(5) 520

[36] Armand L 1997 Ph D Thesis ANU Canberra 393 p

[37] Waelbroeck C, Labeyrie L, Duplessy JC, Guiot J, Labracherie M, Lelaire H and Duprat J 1998 Paleoceanography 13(3) 272

[38] Pichon JJ, Labeyrie L, Bareille G, Labracherie M, Duprat J and Jouzel J 1992 Paleoceanography 7289

[39] Zielinski U, Gersonde R, Sieger R and Fütterer D 1998 Paleoceanography 13(4) 365

[40] Kucera M, Rosell-Melé A, Schneider R, Walbroeck C and Weilnet M 2005 Quat. Sci. Rev. 24813

[41] Crosta X and Koç N 2007 Proxies in Late Cenozoic Paleoceanography (Developments in Marine Geology vol 1) ed C Hillaire-Marcel and A de Vernal (Amsterdam: Elsevier) chapter 8 p 327

[42] Polyak L et al. 2010 Quat. Sci. Rev. 291757

[43] Adams B et al. 2009 Antarctic Climate Change and the Environment SCAR 183

[44] Gersonde R and Zielinski U 2000 Palaeogeogr. Palaeoclimatol. Palaeoecol. 162263

[45] Gersonde R, Crosta X, Abelmann A and Armand L 2005 Quat. Sci. Rev. 24869

[46] CLIMAP 1981 Geol. Soc. Am. Map Chart Ser. MC-36

[47] Burckle L, Robinson D and Cooke D 1982 Nature 299435

[48] Stephens BB and Keeling RF 2000 Nature 404171

[49] Morales-Maqueda MA and Rahmstorf S 2002 Geophys. Res. Lett. 29(1) doi: 10.1029/2001GL013240

[50] Cooke D and Hays JD 198. Antarctic Geoscience The Union of Wisconsin Press 1017

[51] Schweitzer P 1995 U.S. Geological Survey Digital Data Series Virginia

[52] Orsi A, Whitworth T and Nowlin W 1995 Deep-Sea Res. 42(5) 641

[53] Koç N, Jansen E and Haflidason H 1993 Quat. Sci. Rev. 12115

[54] Berner K, Koç N and Godtliebsen F 2010 The Holocene 20(2) 245

[55] Andersen C, Koç N and Moros M 2004 Quat. Sci. Rev. 232155

[56] Solignac S., Giraudeau J and de Vernal A 2006 Paleoceanography 21 doi: 10.1029/2005PA001175 
[57] Hodell DA, Kanfoush SL, Shemesh A, Crosta X, Charles CD and Guilderson TP 2001 Quat. Res. 56191

[58] Crosta X, Debret M, Denis D, Courty M-A and Ther O 2007 Geochem. Geophys. Geosyst. 8(11) doi: 10.1029/2007GC001718

[59] Berner K, Koç N, Divine D, Godtliebsen F and Moros M 2008 Paleoceanography 23 doi: 10.1029/2006PA001339

[60] Kumar N, Anderson R, Mortlock R, Froelich P, Kubik P, Dittrich-Hannen B and Suter M 1995 Nature 378675

[61] Shemesh A, Mortlock R and Froelich P 1989 Paleoceanography 4(3) 221

[62] Hendry K, and Rickaby R 2008 Paleoceanography 23 doi: 10.1029/2007PA001576

[63] Belt S, Massé G, Rowland S and Rohmer M 2007 Org. Geochem. 3816

[64] Willmott V, Rampen S, Domack E, Canals M, Sinninghe Damsté J and Schouten S 2009 Antarctic Science 22(1) 3

[65] Ingalls AE, Anderson RF and Pearson A 2004 Marine Chemistry 9291

[66] Brown TA et al. 2010 Polar Biology doi: 10.1007/s00300-010-0942-5

[67] Massé G, Rowland S, Sicre M, Jacob J, Jansen E and Belt S 2008 Earth Planet. Sci. Lett. 269565

[68] Vare L, Massé G, Gregory T, Smart C and Belt S 2009 Quat. Sci. Rev. 28(13-14) 1354

[69] Barbara L, Crosta X, Massé G and Ther O 2010 Quat. Sci. Rev.29 2731

[70] Denis D, Crosta X, Barbara L, Massé G, Renssen H, Ther O and Giraudeau J 2010 Quat. Sci. Rev. 293709

[71] Massé G, Rowland S, Crosta X, Schmidt S and Belt S submitted Deep-Sea Res. I

[72] Mayewski PA et al. 2004 Quat. Res. 62243

[73] Renssen H., Seppä H, Heiri O, Roche D, Goosse H and Fichefet T 2009 Nat. Geosci. 2411

[74] Debret M, Sebag D, Crosta X, Massei N, Chapron E., Bout-Roumazeilles V and Petit JR 2010 Quat. Sci. Rev. 28(25-26) 2675

[75] Anderson RF, Chase Z, Fleisher MQ and Sachs J 2002 Deep-Sea Res. II 491909

[76] Crosta X and Shemesh A 2000 Paleoceanography 17(1) doi: 10.1029/2000PA000565

[77] Brzezinski MA et al. 2002 Geophys. Res. Lett. 29(12) doi: 10.1029/2001GL014349

[78] Beucher C, Brzezinski MA and Crosta X 2007 Global Biogeochem. Cycles 21 doi: 10.1029/2006GB002746

[79] Cortese G, Gersonde R, Hillenbrand CD and Kuhn 2004 Earth Planet. Sci. Lett. 224509

[80] Sigman DM, Jaccard SL and Haug G 2004 Nature 42859

[81] Mahowald NM et al. 2005 Glob. Biogeochem. Cyc. 19(4) doi: 10.1029/2004GB002402

[82] Bareille G, Labracherie M, Bertrand P, Labeyrie L, Lavaux G and Dignan M 1998 J. Marine Systems 17527

[83] Arrigo KR, van Dijken GL and Bushinsky E 2008 J. Physics Res. $\mathbf{C 1 1 3}$ doi: 10.1029/2007JC004551

[84] Rose KA, Sikes EL, Guilderson TP, Shane P, Hill TM, Zahn R and Spero H 2010 Nature 466 1093

[85] Rampen SW, Schouten S, Koning E, Brummer G and Sinninghé Damsté J 2008 Earth Planet. Sci. Lett. 276207

[86] Lamy F, Hebbeln D, Röhl U and Wefer G 2001 Earth Planet. Sci. Lett. 185369

[87] De la Rocha C, Brzezinski M, DeNiro M and Shemesh A 1998 Nature 395680

[88] Robinson RS, Brunelle BG, Sigman DM 2004 Paleoceanography 19 doi: 10.1029/2003PA000996

[89] Swann GE, Maslin MA, Leng MJ, Sloane HJ and Haug GH 2006 Paleoceanography 21 doi: 10.1029/2005PA001147

[90] Shemesh A, Burckle LH and Hays JD 1994 Science 2661542

[91] Shemesh A, Hodell D, Crosta X, Kanfoush S, Charles C and Guilderson T 2002 Paleoceanography 17(4) doi: 10.1029/2000PA000599 
[92] Altabet MA and François R 1994 Global Biogeochem. Cycles 8(1) 103

[93] De la Rocha C, Brzezinski M, DeNiro MJ 1997 Geochim. Cosmochim. Acta 61(23) 5051

[94] Robinson RS, Sigman D, DiFiore PJ, Rohde MM, Mashiotta TA and Lea DW 2005 Paleoceanography 20(3) doi:10.1029/2004PA001114

[95] Hutchins DA and Bruland KW 1998 Nature 393561

[96] Takeda S 1998 Nature 393774

[97] Matsumoto K, Sarmiento JL and Brzezinski MA 2002 Global Biogeochem. Cycles 16(3) doi: 10.1029/2001GB001442

[98] Crosta X, Shemesh A, Etourneau J, Yam R, Billy I and Pichon JJ 2005b Global Biogeochem. Cycles 19 doi: 3010.1029/2004GB002344

[99] Brunelle B, Sigman D, Cook M, Keigwin L, Haug G., Plessen B, Schettler G and Jaccard S 2007 Paleoceanography 22 doi: 10.1029/2005PA001205

[100] François R, Altabet MA, Yu EF, Sigman DM, Bacon MP, Frank M, Bohrmann G, Bareille G and Labeyrie LD 1997 Nature 389929

[101] Hay MB, Pienitz R and Thompson RE 2003 Mar. Micropaleontol. 48291

[102] Armand LK, Cornet-Barthaux V, Mosseri J and Quéguiner B 2008 Deep-Sea Res. II 55563

[103] Dabros M and Mudie P 1986 Geological Survey of Canada 86(1A) 107

[104] Beaufort L, de Garidel-Thoron T, Mix A and Pisias N 2001 Science 2932440

[105] Schmidt D, Thierstein H and Bollman J 2004 Palaeogeogr. Palaeoclimatol. Palaeoecol. 212159

[106] Weller A and Girault F Submitted Mar. Micropaleontol.

[107] Popp BN, Laws EA, Bidigare RR, Dore JE, Hanson KL and Wakeham SG 1998 Geochim. Cosmochim. Acta 62(1) 69

[108] Lourey MJ, Trull TW and Sigman D 2003 Global Biogeochem. Cycles 17(3) doi: 10.1029/2002GB001973

[109] Varela DE, Pride CJ and Brzezinski MA 2004 Global Biogeochem. Cycles 18 doi: $10.1029 / 2003 \mathrm{~GB} 002140$

[110] Tortell PD and Morel FMM 2002 Limnol. Oceanog. 47(4) 1012

[111] Karsh KL, Trull TW, Lourey MJ and Sigman DM 2003 Limnol. Oceanog. 48(3) 1058

[112] Sigman DM, Altabet MA, François R, McCorkle DC and Gaillard JF 1999 Paleoceanography 14(2) 118

[113] Cardinal D., Alleman LY, de Jong J, Ziegler K and André L 2003 J. Anal. Atom. Spectro. 18213

[114] Brzezinski M, Jones J, Beucher C, Demarest M and Berg H 2006 Anal. Chem. 78(17) 6109.

[115] Swann GE, Maslin MA, Leng MJ, Sloane HJ and Haug GH 2006 Paleoceanography 21 doi: 10.1029/2005PA001147

[116] Annett AL, Crosta X, Clarke AC and Ganeshram R 2010 Polar Biology 3313 